\title{
Effects of Productivity Growth on Employment Generation, Capital Accumulation and Economic Growth in Uganda
}

\author{
Jimmy Alani, Member, IACSIT
}

\begin{abstract}
The study examined the effects of productivity growth on employment, capital accumulation and economic growth in Uganda within the 1972 to 2008 period. Econometric method was used in the empirical analyses. First, we found that reduction in economic growth might have come from productivity growth, and that productivity growth might have caused unemployment and depletion of capital stock. Second, we found that both labor and capital productivity growth might have caused unemployment, decline in both capital accumulation and economic growth. Third, the study found that economic growth, capital accumulation and employment, might have resulted from technical progress.
\end{abstract}

Index Terms-Capital accumulation, economic growth, effects, employment, productivity.

\section{INTRODUCTION}

Technology refers to knowledge required to produce the goods and services. Increase in technical progress causes labor to be more skilful and innovative and able to perform more tasks within a given period. Capital stock refers to goods used to produce other goods. Increase in capital stock provides labor with more tools to work with in production more goods and services. Generally most economists contend that increase in productivity results in output growth. However, theoretical models provide contrary views.

Their argument is contrary to the ideas that this study is putting forward that growth in labor productivity causes: (a) decline in economic growth, (b) reduction in capital accumulation and (c) unemployment, the reason being that growth in productivity prompts labor to substitute leisure for work and that when productivity of a worker grows he would accomplish his regular (daily) tasks within a shorter period of time and spend the rest of the time he has spared to do his own work or enjoy leisure. It may also be due to the fact that wages are fixed and are not adjusted as productivity increases Thus, increase in productivity would result in faster depletion of output in terms of raw materials which ought to be paid for if production is to continue.

The study however, supports the argument advanced by some economists that slowdown in labor productivity growth appear to be strongly related to employment growth. Theory from the Cobb-Douglas production function shows that decline in technological advancement, growth in capital productivity or labor productivity growth results in declines in output growth leading to increase in excess demand and

Manuscript received March 18, 2012; revised May 15, 2012

J. Alani is with Department of Economics and Business Education, Faculty of Education and Humanities, Gulu University, P. O. Box 166, Gulu, Uganda (e-mail: j.alani@gu.ac.ug). inflation. Whereas a rise in technological progress and decline in capital or labor productivity leads to reductions in excess demand and increases interest rates.

Although control of inflation and high interest rates might have been possible through technological advancement and rising productivity, the policy option of using technological progress and productivity to control excess demand, inflation and high interest rates has not been forthcoming.

That could have been so because Uganda is still a less developed country with low levels of both technology and industrialization. It could also have been because the government of Uganda was contented with controlling inflation by restricting monetary growth. The outcome of that was persistent high interest rates that tended to hinder investments. Therefore, to some extent it made the economic progress of the country not to be as fast as it could have been.

Hence, there was need to empirically test whether growth in productivity caused capital accumulation, employment and economic growth. The study also empirically simulated and tested the effects of technical progress on the three aforementioned variables. The theoretical models were developed from the Cobb-Douglas production function. The models were then expressed in terms of growth rates.

Econometric models were developed and tested in accordance with the theoretical models. Having performed the necessary tests we arrived at the following findings:

(1) Unemployment growth could have been the result of productivity growth, whereas employment growth could have resulted from technical progress and capital accumulation in Uganda within the period.

(2) Decline in capital accumulation could have resulted from labor productivity growth, but increase in capital accumulation might have originated from technical progress and growth in employment in Uganda within the given period.

(3) Unemployment growth could have been caused by growth in both labor and capital productivity, whereas technical progress could have been the cause of employment growth the given period.

(4) Decline in capital accumulation could have been caused by growth in both capital and labor productivity, but growth in capital accumulation could have come from technological progress.

(5) Economic growth was negatively affected by growth in both labor and capital productivity, but negatively affected by technological progress in Uganda within the 19720 to 2008 period.

\section{Statement of the Problem}

First, in general terms most economists and in particular Casetti and Jones (1983, 1987), Casetti (1982b), Casetti 
(1984a, 1984b) and Hornstein and Krusell (1996) contend that increase in productivity results in output growth. Theoretical models derived from the (i) Cobb-Douglas production function, (ii) profit function and (iii) relationships between leisure, income, labour and capital tend to refute this belief. That may be because the worker tends to substitute leisure for income following the increase in productivity. It may also be due to the fact that wages are fixed and are not adjusted as productivity increases. Thus any increase in productivity may lead to depletion of output.

Second, Carway and Lipsey (2003) argue that total factor productivity (TFP) is often interpreted by many economists to measure technological progress and it promotes economic growth. The major problem identified by Hulten (2000) is that various factors of TFP are not measured directly, but lumped together as residual. They cannot be disaggregated within the pure TFP framework. Moreover TFP is an outcome not a cause of anything and cannot be used by policy makers to affect economic growth.

Therefore, Carway and Lipsey (2003) argue further that TFP may be an indicator but is certainly not a policy instrument. To them TFP, is not a measure of technological change as specified in Solow's seminal 1956 and 1957 articles. Similarly, the study argues that TFP tends to overestimate or underestimate the technical progress. In fact there is growing literature pointing out that productivity change is not an index of technological progress (Gordon, 2000). Therefore, TFP is a misleading concept of productivity because: (a) critical examination of the Cobb-Douglas production function shows that the common TFP exceeds actual TFP by an amount equal to the growth in output, (b) most economists writing on total factor productivity might have not bothered to distinguish it from level of technology.

Third, theory from the Cobb-Douglas production function shows that decline in technological advancement, growth in capital productivity or growth in labor productivity results in declines in output growth leading to increase in excess demand and inflation. Whereas a rise in technological progress and decline in capital or labor productivity leads to reductions in excess demand and increases interest rates.

Lastly, the policy option of using technological progress and productivity to control excess demand, inflation and high interest rates has not been forthcoming. That is because Uganda is still a less developed country with low levels of both technology and industrialization.

It could also be because the government of Uganda is contented with controlling inflation by restricting monetary growth. The outcome of this has been persistent high interest rates that have tended to hinder investments. And to some extent has made the economic progress of the country not to be as fast as it could have been.

\section{OBJECTIVES OF THE STUDY}

The study aims at estimating the following:

(a) The effects of growth in capital stock, capital productivity, labor productivity and technical progress on employment in Uganda.

(b) The effects of growth in labor stock, labor productivity, capital productivity and technical progress on economic growth in the country.

(c) The effects of technical progress, labor productivity and capital productivity on economic growth in the aforementioned country.

\section{LITERATURE REVIEW}

Technology refers to knowledge required to produce the goods and services and as a result increase in technical progress causes labor to be more skilful and innovative and able to perform more tasks within a given period. Capital stock refers to goods used to produce other goods implying that increase capital stock provides labor with more tools to work with to produce more goods and services. Generally most economists contend that increase in productivity results in output growth. Theoretical models derived from the (i) Cobb-Douglas production function, (ii) profit function and (iii) relationships between leisure, income, labor and capital tend to refute this belief.

Their argument is contrary to the ideas that this study is putting forward that growth in labor productivity causes (a) decline in economic growth, (b) reduction in capital accumulation and (c) unemployment, the reason being that growth in productivity prompts labor to substitute leisure for work and that when productivity of a worker grows he would accomplish his regular (daily) tasks within a shorter period of time and spend the rest of the time he has spared to do his own work or enjoy leisure. It may also be due to the fact that wages are fixed and are not adjusted as productivity increases. Thus, increase in productivity would result in faster depletion of output in terms of raw materials which ought to be paid for if production is to continue. However, the study supports the argument advanced by some economists that slowdown in labor productivity growth appear to be strongly related to employment growth.

Although control of inflation and high interest rates might have been possible through technological advancement and rising productivity, the policy option of using technological progress and productivity to control excess demand, inflation and high interest rates was not been forthcoming. That could have been so because Uganda is still a developing country with low levels of both technology and industrialization. It could also have been because the government of Uganda was contented with controlling inflation by restricting monetary growth. The outcome of this was persistent high interest rates that tended to hinder investments. As a result to some extent made the economic progress of the country not to be as fast as it could have been.

The method to estimate the contribution of technological progress in economic growth is often based on the improved Cobb-Douglas production function by Tinbergen (1964) as cited in Liu Sifeng et al (2004: vol. 33, pp. 303-304, Issue 2) and with Solow's (1957: vol. 39, pp. 312-20) "remaining value". According to Liu Sifeng, Solow's "remaining value" represents the contribution of all factors except fund and labour to output ratio. However, Liu Sifeng et al (2004) argues that the method suffers form some serious defects, making it difficult to make reasonable estimates in a practical 
study.

This is because a lot of random factors also affect output growth leading to the overstatement of technological progress. They went ahead to separate influences of other factors from the "remaining value" in order to obtain a better measurement of technological advance.

Although Liu et al (2004), separated the "remaining value" into technological progress and random variation originating from other factors, they only measured the contributions of technological progress to economic growth not its effects on economic growth.

Their method may not be appropriate for estimating the effects of technical progress on economic growth because it does not consider technological progress directly at all. Instead it estimates technological progress through time and may only give a better estimate of effect of time on output, but not that of technology.

One weakness with their model is that it treats economic growth as a function of time only not as technological progress. Thus, we use $Y=A_{0} e^{r t} K^{\alpha} L^{\beta}=A K^{\alpha} L^{\beta}$ Instead of employing the model given by $Y=A^{\lambda} K^{\alpha} L^{\beta}$.

In Liu and Sifeng et al model the level of technology is given and moved only by time. Otherwise this present study is advancing a theory that level of technology varies exponentially with respect to output (i.e. $\lambda \neq 1$ ).

The expression for measuring the rate of technological progress by Solow's "remaining value" is given by $(d \Delta / A)=d(\Delta Y / Y)-\alpha(\Delta K / K)-\beta(\Delta L / L)$.

In case the effects of non-technological progress, is not very pronounced it might be very difficult to obtain reasonable estimates using the "remaining value" formula above. Also, in case, the original data are employed based on a buffer of operation according to the theory advanced by Liu (1991: Vol. 3 No. 1, pp. 57-66), an application of $\operatorname{GM}(1,1)$ simulation and least-squares estimation may be employed to remove the influence of non-technological progress and random inflation. As a result the estimated parameters and the relationship of output with fund, labor and the technological progress are made more accurate (Liu 2004: Vol. 33 No 2, p. 304).

Branson (1989: 481-484) advances an ingenious theory of production and employment. But it does not tally with the theoretical construct and empirical results that may be derived from the Cobb-Douglas production function. This may be the case because whenever either labor or capital productivity rises, producers (firms) would prefer to employ less labor or capital at the given wage rate or rental rate of capital respectively. At the same time workers would react to the increased productivity by producing the same amount of output as before with less amount of labor while earning the same wage rate as before. The worker therefore, trades off leisure with work. On the demand side the producers would tend to reduce their demand for labor because they would prefer to produce the same amount of output by employing less labor because labor productivity has increased in order to generate more profits.

Generally, when output falls as productivity rises leading to the inverse relationship between productivity and output $\frac{\partial Y}{\partial K_{P}}=\left(\frac{-\alpha}{1-\alpha-\beta}\right)\left[\frac{Y^{(1+\alpha+\beta)}}{K_{P}}\right] . \therefore \frac{\partial Y}{\partial L_{P}}=\left(\frac{-\beta}{1-\alpha-\beta}\right)\left[\frac{Y^{(1+\alpha+\beta)}}{L_{P}}\right]$ since the feasible area of production lies in the region where there is decreasing returns to scale i.e. $0<\alpha+\beta<1$.

Furthermore, the market labor supply curve is the sum of individual labor supply curves (Dwivedi 2003, pp. 426-439). As incomes reach the desired level for comfortable standard of living workers tend to prefer more leisure while higher wage rates create a disincentive for longer hours of work (Koutsoyaiannis 1979, p. 450) and therefore workers would find it rational to work less to produce the output in case their productivity has increased (my emphasis).

Schiller (2006) takes economic growth in the US to depend on increase in average productivity per worker. Moreover, Schiller (2006) reports that between 1978 and 1984 growth in productivity slowed dramatically and prevented GDP growth (Schiller, 2006: pp. 359-340).

The finding Schiller (2006) is advancing is contrary to the ideas that this study is putting forward that growth in labor productivity causes: (a) decline in economic growth, (b) reduction in capital accumulation and (c) unemployment. That is because growth in productivity prompts labor to trade off leisure for work and that when productivity of a worker grows. He would then accomplish his regular (daily) tasks within a shorter period of time. Consequently, he spends the rest of the time spared to do his own work or enjoy leisure. Otherwise, increase in productivity would result in faster depletion of output in terms of raw materials which ought to be paid for if production is to continue.

The study refutes Schiller (2006), Gomez-Salvador et al. (2006) contention that "productivity gains are a key factor driving long-run growth". However, the study supports claim advanced by Gomez-Salvador et al. (2006), that slowdown in labor productivity growth appear to be strongly related to employment growth particularly in US and EURO area. Gomez-Salvador et al. (2006) adds that productivity growth is a primary source of growth in real output per capita. In fact, in their empirical analyses they found that from 1950 to 2005 US and EURO area there was an inverse labor productivity and economic growth (Gomez-Salvador, 2006: pp. 1-133).

This claim is contrary to the idea the study is advancing that productivity growth results in decline in employment, capital accumulation as well as in economic growth, based on the Cobb-Douglas production theory. Hence, there is need to empirically test whether growth in productivity causes capital accumulation, employment and economic growth. The study has also empirically simulated and tested the effects of technical progress on the three aforementioned variables.

Productivity, technology and economic growth may be modeled by making use of leisure, consumption (income) and labor in man-hours. Let the relationship between leisure (and income (consumption) be given by $Y_{1}=a_{1}-b_{1} Z_{1}$ where $Y_{1}$ is total consumption (income), $a_{1}$ is an intercept, $b_{1}$ is a parameter and $Z_{1}$ is the amount of leisure time. Here $L=W-Z$, where $L$ is labor time and $W$ is the total amount of time available and can be apportioned for leisure $(Z)$ and work $L$, whereas leisure $Z_{1}$, is a function of labor productivity $(Y / L))=L_{P}$ i.e. $Z_{1}=f(Y / L)=t_{1} \cdot L_{P}$. 
Thus $Y_{1}=a_{1}-b_{1} t_{1} \cdot L_{P} \cdot\left(d Y_{1} / Y_{1}\right)=-r_{1} \cdot\left(d L_{P} / L_{P}\right)$.

Similarly, for capital $\left(d Y_{2} / Y_{2}\right)=-r_{2} \cdot\left(d K_{P} / K_{P}\right)$.

Furthermore, let output be a function of technology as expressed by $Y_{3}=r_{3} \cdot A^{\eta}$ or $\left(d Y_{3} / Y_{3}\right)=\eta \cdot(d A / A)$.

Combining the contributions of technical progress $\left(d Y_{3} / Y_{3}\right)=\eta \cdot(d A / A) \quad$ capital productivity growth $\left(d Y_{2} / Y_{2}\right)=-r_{2} \cdot\left(d K_{P} / K_{P}\right)$ and labor productivity growth $\left(d Y_{1} / Y_{1}\right)=-r_{1} \cdot\left(d L_{P} / L_{P}\right)$ towards economic growth $d Y / Y$ provides the expression:

$(d Y / Y)=\eta(d A / A)-r_{1} \cdot d\left(L_{P} / L_{P}\right)-r_{2} \cdot d\left(K_{P} / K_{p}\right)$

where $\eta, r_{1}$ and $r_{2}$ are parameters.

Hence growth in both capital and labor productivity leads to decline in economic growth, whereas technological progress gives rise to economic growth.

\section{A. Theoretical Framework}

The theoretical models 1 and 2 below were developed from the Cobb-Douglas production function given by $Y=A^{\lambda} K^{\alpha} L^{\beta}$

where $Y$ is output (GDP), $A$ is level of technology, $K$ is capital stock, $L$ is labor stock, $\lambda$ is coefficient on level of technology, and $\alpha$ and $\beta$ are parameters of returns to scale.

Manipulating the Cobb-Douglas production function given above provides Equations 1, 2, 3, 4 and 5 given below in terms of growth rates.

\section{B. Labor Productivity Growth Leads to Unemployment}

The mathematical equation (1) below implies that productivity growth $d L p / L p$ causes growth in unemployment (i.e. reduction in employment), whereas both technical progress $d A / A$ and capital accumulation $d K / K$ result in labor employment growth $d L / L$.

$$
\frac{d L}{L}=\frac{1}{1-\beta}\left[\lambda \frac{d A}{A}-\frac{d L_{P}}{L_{P}}+\alpha \frac{d K}{K}\right]
$$

We take the economy to be operating under decreasing returns to scale i.e. $\alpha+\beta<1$ because the economy is operating within the feasible region of production. The parameters $\lambda, \alpha, \beta$ are all positive. Similarly, the variables $L, A, L p, K$ are all positive, but their growth rates may be either positive or negative. Increase in capital productivity may result in unemployment because a rise in productivity may cause laborers to substitute leisure for work.

Technology refers to knowledge required to produce the goods and services and as a result increase in technical progress cause labor to be more skilful and innovative and able to perform many tasks within a given period.

Capital stock refers to goods used to produce other goods implying that increase capital stock provides labor with more tools to work with to produce more goods and services.

\section{Capital Productivity Growth Results in Decline in Capital Accumulation}

As depicted by equation 2, increase in technical progress (i.e. applied knowledge to produces capital goods) results in more capital accumulation. Whereas, growth in capital productivity $d K p / K p$ brings about reduction in capital accumulation because it may lead to faster depletion of the existing capital in order to acquire more raw materials required to produce more capital. Raising the level of labor to produce more capital goods brings about faster accumulation of capital. It is labor that produces capital. Therefore, the more labor is engaged in the production of capital goods the faster is the capital accumulation.

$$
\frac{d K}{K}=\frac{1}{1-\alpha}\left[\lambda \frac{d A}{A}-\frac{d K_{P}}{K_{P}}+\beta \frac{d L}{L}\right]
$$

where $0<\alpha, \beta<1$ a phenomenon of constant returns to scale.

\section{Both Capital and Labor Productivity Growth Result in Unemployment}

Equation (3) captures both the influence of both capital and capital productivity on unemployment and we take growth in labor supply to be a function of growth in technical progress, labor productivity and capital productivity.

$$
\frac{d L}{L}=\frac{1}{1-\alpha-\beta}\left[\lambda \frac{d A}{A}-\alpha \frac{d K_{P}}{K_{P}}-(1-\alpha) \frac{d L_{P}}{L_{P}}\right] \ldots
$$

where the coefficients represent the respective elasticity of labor supply.

\section{E. Both Capital and Labor Productivity Growth Result in Reduction in Capital Accumulation}

Equation (4) captures both the influence of both capital and capital productivity on capital accumulation and we take capital stock to be a function of technical progress, labor productivity and capital productivity.

$$
\frac{d K}{K}=\frac{1}{1-\alpha-\beta}\left[\lambda \frac{d A}{A}-(1-\beta) \frac{d K_{P}}{K_{P}}-\beta \frac{d L_{P}}{L_{P}}\right] .
$$

where the respective coefficients represent a given elasticity of capital stock.

\section{F. Both Capital and Labor Productivity Growth Result in Reduction in Economic Growth}

Expansion in applied knowledge to produce goods and services (i.e. technical progress) give rise to economic growth, whereas increase in productivity results if faster depletion of output and trade off of leisure for work resulting in reduction in economic growth as depicted by equation (5).

$$
\frac{d Y}{Y}=\frac{1}{1-\alpha-\beta}\left[\lambda \frac{d A}{A}-\alpha \frac{d K p}{K p}-\beta \frac{d L p}{L p}\right] \ldots \ldots \ldots
$$

\section{G. Methodology}

Econometric models were developed in accordance with the five theoretical models given above. First, we take labor productivity growth lead to unemployment, whereas both growth in technological progress and capital stock cause increase in labor supply as portrayed by model (6). 


$$
\frac{d L t}{L t}=\beta_{1} \frac{d A t}{A t}+\beta_{2} \frac{d L p_{t}}{L p_{t}}+\beta_{3} \frac{d K t}{K t}+\varepsilon_{t}
$$

where $\beta_{1}>0, \beta_{2}<0, \beta_{3}>0$ and $\mathcal{E}$ is the error term.

Second, we expect capital productivity growth to cause decline in capital accumulation, whereas both growth in labor stock and technical progress result in capital accumulation as given by model (7).

$$
\frac{d K t}{K t}=\beta_{1} \frac{d A t}{A t}+\beta_{2} \frac{d K p_{t}}{K p_{t}}+\beta_{3} \frac{d L t}{L t}+\varepsilon_{t} \cdots \cdots \cdots \cdots
$$

where $\beta_{1}>0, \beta_{2}<0, \beta_{3}>0$ and $\mathcal{E}$ is the disturbance term.

Third, we expect capital and labor productivity growth to create unemployment, whereas technical progress generates employment growth. See regression model (8) given below.

$$
\frac{d L t}{L t}=\beta_{1} \frac{d A t}{A t}+\beta_{2} \frac{d L p_{t}}{L p_{t}}+\beta_{3} \frac{d K p_{t}}{K p_{t}}+\varepsilon_{t}
$$

where $\beta_{1}>0, \beta_{2}<0, \beta_{3}<0$ and $\mathcal{E}$ is the error term.

Fourth, both capital and productivity growth result in reduction in capital accumulation, whereas technical progress leads cause capital accumulation. See regression model (9).

$$
\frac{d K t}{K t}=\beta_{1} \frac{d A t}{A t}+\beta_{2} \frac{d L p_{t}}{L p_{t}}+\beta_{3} \frac{d K p_{t}}{K p_{t}}+\varepsilon_{t} \cdots \cdots \cdots
$$

where $\beta_{1}>0, \beta_{2}<0, \beta_{3}<0$ and $\mathcal{E}$ is the error term.

Both capital and labor productivity growth results in reduction in economic growth, whereas technical progress leads to increase in economic growth. See regression model (10) given below.

$$
\frac{d Y t}{Y t}=\beta_{1} \frac{d A t}{A t}+\beta_{2} \frac{d L p_{t}}{L p_{t}}+\beta_{3} \frac{d K p_{t}}{K p_{t}}+\varepsilon_{t} \cdots \cdots . . .
$$

where $\beta_{1}>0, \beta_{2}<0, \beta_{3}<0$ and $\mathcal{E}$ is the error term.

\section{H. Hypotheses}

The hypotheses of the study are as follows:

1. Labor productivity capital growth leads to unemployment.

2. Capital productivity labor growth results in decline in capital accumulation.

3. Both capital and labor productivity growth result in unemployment.

4. Both capital and labor productivity growth result in reduction in capital accumulation.

5 . Both capital labor productivity growth cause reduction in economic growth.

\section{EMPIRICAL RESUlTS AND CONCLUSIONS}

The econometric models were estimated in accordance with equations 5, 6, 7, 9 and 10. Using data from Uganda from 1971 to 2008 consisting of 37 observations after adjusting endpoints we obtained the regression models 1, 2, 3, 4 and 5 given below. In all the regression results the $p$-value $=0.0000$. Thus $p$-value is the probability of obtaining a value of and $t$ test statistic as much as or grater than the computed $t$ value. In other words $p$-value is the lowest significance at which the null hypothesis can be rejected.

Therefore with $p$-value $=0.0000$ the null hypothesis can be rejected with absolute confidence.

Also for 33 degrees of freedom at 0.001 level of significance the $t$ value of 3.6 is greater in absolute terms than all the computed $t$ values obtained. Hence, under the null hypothesis that a given coefficient value was zero we, reject the null hypothesis.

In every case computed $F=0.000000$ value was greater than the critical $F=7.5$ and they followed $F$ distribution with 3 and 33 degrees of freedom in the numerator and denominator respectively. (Note that there are 37 observations and three explanatory variables). From the table we found that in all five regressions, the $F$ was significant at 1 percent level of significance.

In each of the five regression results given below, the coefficient of multiple determination, $R^{2}$ and adjusted $R^{2}$ (i.e. $\bar{R}^{2}$ ) showed that the independent variables together could explain over 93 percent of the variations in the dependent variable. In all the five regression results with 37 degrees of freedom the computed Durbin-Watson statistic $D . W$. was greater than the table D.W. $=d_{U}=1.66$ at 5 percent level of significance, confirming that there was no serial correlation (i.e. autocorrelation) problem.

From regression result Table1we inferred that labor unemployment growth could have been as a result of productivity growth, whereas employment growth could have resulted from technical progress and capital accumulation in Uganda within the 1972 to 2008 period.

TABLE I: REGRESSION RESULT 1

\begin{tabular}{cccccc}
\hline \hline$\frac{d \hat{L}}{L(-1)}$ & $=$ & $1.200042 \frac{d A}{A(-1)}$ & $-1.561060 \frac{d L p}{L p(-1)}$ & + & $0.535472 \frac{d K}{K(-1)}$ \\
s.e. & $=$ & 0.100073 & 0.043807 & 0.0400033 \\
$t$ & $=$ & 11.99173 & -35.63529 & & 13.37567 \\
$p-$ value & $=$ & 0.0000 & 0.0000 & 0.0000 \\
$R^{2}$ & $=$ & 0.975285 & $\bar{R}^{2}$ & $=$ & 0.9753831 \\
$D . W$. & $=$ & 2.015049 & $F$ & $=$ & 670.835 \\
\hline
\end{tabular}

From regression result 2 we inferred that decline in capital accumulation could have resulted from labor productivity growth, but increase in capital accumulation might have originated from technical progress and growth in employm (dint in Uganda within the given period.

TABLE II: REGRESSION RESULT 2

\begin{tabular}{cccccc}
\hline \hline$\frac{d \hat{K}}{K(-1)}$ & $=$ & $1.432971 \frac{d A}{A(-1)}$ & $-1.408902 \frac{d K p}{K p(-1)}$ & + & $0.404073 \frac{d L}{L(-1)}$ \\
s.e. & $=$ & 0.016414 & 0.010826 & & 0.005350 \\
$t$ & $=$ & 87.30436 & -130.1392 & & 75.52897 \\
$p-$ value & $=$ & 0.0000 & 0.0000 & & 0.0000 \\
$R^{2}$ & $=$ & 0.977142 & $\bar{R}^{2}$ & $=$ & 0.975797 \\
D.W. & $=$ & 1.923563 & F-Statistic & $=$ & 726.7244 \\
\end{tabular}


From regression result 3 we inferred that unemployment growth could have been caused by growth in both labour and capital productivity, whereas technical progress could have been the cause of employment growth in Uganda within the given period.

TABLE III: REGRESSION RESULT 3

\begin{tabular}{cccccc}
\hline \hline$\frac{d \hat{L}}{L(-1)}$ & $=$ & $2.491685 \frac{d A}{A(-1)}$ & $-1.980190 \frac{d L p}{L p(-1)}$ & $-0.931889 \frac{d K p}{K p(-1)}$ \\
s.e. & $=$ & 0.117428 & 0.066729 & & 0.083351 \\
$t$ & $=$ & 21.21889 & -29.67922 & & -11.18035 \\
$p-$ value & $=$ & 0.0000 & 0.0000 & & 0.0000 \\
$R^{2}$ & $=$ & 0.966905 & $\bar{R}^{2}$ & $=$ & 0.964958 \\
$D . W$. & $=$ & 2.029625 & $F-$ Statistic & $=$ & 496.6757 \\
& & & & & \\
\hline
\end{tabular}

From regression result 4 we inferred that decline in capital accumulation could have been caused by growth in both capital and labor productivity, but growth in capital accumulation could have come from technological progress in Uganda within the 1972 to 2008 period.

TABLE IV: REGRESSION RESULT 4

\begin{tabular}{cccccc}
\hline \hline$\frac{d \hat{K}}{K(-1)}$ & $=$ & $2.450229 \frac{d A}{A(-1)}$ & $-1.794558 \frac{d K p}{K p(-1)}$ & $-0.811241 \frac{d L p}{L p(-1)}$ \\
s.e. & $=$ & 0.031351 & 0.022253 & 0.017813 \\
$t$ & $=$ & 78.15368 & -80.64215 & & -45.54165 \\
$p-$ value & $=$ & 0.0000 & 0.0000 & & 0.0000 \\
$R^{2}$ & $=$ & 0.937775 & $\bar{R}^{2}$ & $=$ & 0.934115 \\
$D . W$. & $=$ & 1.994822 & $F-$ Statistic & $=$ & 256.2018 \\
\end{tabular}

From regression result 5 we inferred that economic growth was negatively affected by growth in both labor and capital productivity, but negatively affected by technological progress in Uganda within the 19720 to 2008 period. ........ (14)

TABLE V: REGRESSION RESULT 5

\begin{tabular}{cccccc}
\hline \hline$\frac{d \hat{Y}}{Y(-1)}$ & $=$ & $2.434768 \frac{d A}{A(-1)}$ & - & $0.727085 \frac{d K p}{K p(-1)}$ & $-0.811202 \frac{d L p}{L p(-1)}$ \\
s.e. & $=$ & 0.030956 & 0.021973 & 0.017589 \\
$t$ & $=$ & 78.65143 & -33.08955 & & -46.12053 \\
$p-$ value & $=$ & 0.0000 & 0.0000 & & 0.0000 \\
$R^{2}$ & $=$ & 0.990936 & $\bar{R}^{2}$ & $=$ & 0.990403 \\
D.W. & $=$ & 2.082433 & $F-$ Statistic & $=$ & 1858.494 \\
\end{tabular}

\section{REFERENCES}

[1] W. H. Branson, Macroeconomic Theory and Policy, $3^{\text {rd }}$ edition, Harper and Row, New York, 1989.

[2] K. I. Carlaw, and R. G. Lipsey, "Productivity, Technology and Economic Growth: What is the Relationship?" Blackwell Publishing Ltd, Oxford, Journal of Economic Surveys, vol. 17, no. 3, pp. 457-487, 2003.
[3] E. Casetti, and J. P. III. Jones, "Regional Shifts in the Manufacturing Productivity Response to Output Growth," Sunbelt versus Snowbelt, Urban Geography, vol. 4, pp. 285-301, 1983.

[4] E. Casetti, and J. P. III. Jones, "Spatail Aspects of Productivity Slowdown: An Analysis of U.S. Manufacturing Data," Annals of Association of American Geographers, vol. 77, no. 1, pp. 76-88, 1987.

[5] C. W. Cobb and P. H. Douglas, "Theory of Production," American Economic Review, vol. 18 (supplement), pp.169-165, 1929.

[6] A. Desai, "India's Technological Capacity: An Analysis of Its Achievements and Limits," Research Policy, vol.13, no.5, pp.303-310.

[7] E. T. Dowling, Introduction to Mathematical Economics (Third Edition), Tata McGraw-Hill Publishing Company Ltd., New Delhi, 2001.

[8] D. N. Dwivedi, Microeconomics: Theory and Applications, S. K. Publishers, Delhi, 2003.

[9] R. Gomez-Salvador, "Labour Productivity and Development in EURO Area," European Central Bank, Occasional Paper Series, no. 53, October, 2006.

[10] W. Greene, Econometric Analysis, Prentice-Hall, Inc.; Upper Saddle River, New Jersey, 1997.

[11] D. N. Gujarati, Basic Econometrics, Tata McGraw-Hill Publishing Company Ltd., New Delhi, 2004.

[12] A. Hornstein and P. Krusell, "Can Technology Improvements Cause Productivity Slowdowns?” NBER Macroeconomics Annals, University of Chicago Press, vol. 11, pp. 209-259, 1996.

[13] C. R. Hulten, "Total Factor Productivity: A Short Biography," NBER Working Paper, 7471, National Bureau of Economic Research, Washington, Review, vol. 65, pp. 126-136, 2000.

[14] J. Johnston, Econometric Methods. McGraw-Hill Book, Singapore, 1984.

[15] A. Koutsoyiannis, Modern Microeconomics (2 ${ }^{\text {nd }}$ edition), Thomas Press ltd, India, 1979.

[16] A. Koutsoyiannis, Theory of Econometrics (2 ${ }^{\text {nd }}$ edition), Replika Press Pvt, Ltd, Kundli, India, 2001.

[17] S. Liu, Buffer Operator and Its Application, Science Press, Beijing, 1991.

[18] S. Liu, "The G-G-D Model and Technical Change," Cabernets, vol.33, issue 2, pp.303-309, 2004; no.12, pp.1693-1701, 1990.

[19] J. D. Sachs and B. F. Larrain B. 1993, Macroeconomics in the Global Economy, Upper Saddle River, Prentice-Hall Inc, New Jersey 1993.

[20] B. R. Schiller, The Macro economy Today (Tenth Edition), McGraw-Hill Irwin, Boston, 2006.

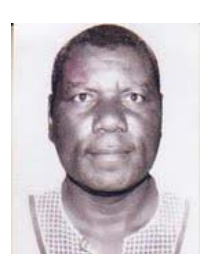

Mr. Jimmy Alani is a Ugandan. He was born on $11^{\text {th }}$ April, 1961. Since September 1, he has been lecturing in economics at Gulu University in northern Uganda. The author obtained his B. Sc. Statistics from Makerere University in March 1990, M. A. in Economic Policy and Planning from Makerere University in January 1996 and M. A. in International Political Economy in March 2001 from University of Tsukuba. Currently he is pursuing a $\mathrm{PhD}$ course in Economics at Makerere University. His PhD dissertation is on "Effects of Technological Progress and Productivity in Uganda: Simulation and Econometric Approach".

Before becoming a lecturer at Gulu University he served as an ECONOMIST at the Ministry of Finance, Planning and Economic Development in Uganda. Mr. Jimmy Alani is currently a member of International Development Economics and Research Center Scientific Committee. 